\title{
Entrepreneurial skill development in Indonesia and Nigeria through project-based learning
}

\author{
Muhammad Kristiawan $^{1}$, Henry Samuel Edosomwan ${ }^{2}$, Sheren Dwi Oktaria ${ }^{1}$, Elsa Viona $^{1}$ \\ ${ }^{1}$ Universitas Bengkulu, Indonesia \\ ${ }^{2}$ Nnamdi Azikiwe University, Awka, Nigeria
}

\begin{tabular}{l} 
Article Info \\
\hline Article history: \\
Received Aug $13^{\text {th }}, 2021$ \\
Revised Sept $16^{\text {th }}, 2021$ \\
Accepted Oct $17^{\text {th }}, 2021$ \\
\hline
\end{tabular}

\section{Keyword:}

Project based learning Entrepreneurial skills

Learning quality

\begin{abstract}
This study aim to analyze how students in Indonesia and Nigeria used ProjectBased Learning to develop their entrepreneurial skills. Qualitative methods with observation sheet and students' project document were used as instruments in this study. The subjects were student whom join course entrepreneurship in Nnamdi Azikiwe University and Universitas Bengkulu. The success of the Project-Based Learning strategy is evaluated by reviewing projects completed by students. The results obtained in Nnamdi Azikiwe University and Universitas Bengkulu indicated that $\mathrm{PjBL}$ approach increases students' entrepreneurship skill development, creative thinking, and problem solving. The findings of this study can be used by universities in Indonesia, Nigeria, and other countries as an alternative learning strategy. These are very important for everyone in the future. Hence, PjBL is an effective method that can be used to enhance the entrepreneurial skill of students compared to the traditional class structure where the teacher or lecturer do more of the teaching with less students' involvement. This study provides an alternative option for developing entrepreneurial skills through project-based learning in both Indonesia and Nigeria.
\end{abstract}

(C) 2021 The Authors. Published by IICET.

This is an open access article under the CC BY-NC-SA license (https://creativecommons.org/licenses/by-nc-sa/4.0)

\section{Corresponding Author:}

Muhammad Kristiawan,

Universitas Bengkulu

Email: muhammadkristiawan@unib.ac.id

\section{Introduction}

The research began from the publication of Regulation of the Minister of Education and Culture No. 3 of 2020, also known as the Merdeka Belajar-Kampus Merdeka. The Independent Campus Policy is a policy that allows students to study for a maximum of three semesters outside of their program of study. Also, in 2014, the Nigerian University Commission (NUC), made entrepreneurial studies compulsory for all students, irrespective of the course of study. This is because of the changing nature of the labour market and to help student persue other interest and build utility skills that will be helpful during business creation and planning. This allows students to undertake entrepreneurial studies for a semester, and then take up practical skill of interest in another. For instance, In Nnamdi Azikiwe University, Awka, Nigeria (2011) the 'Chike Okoli Centre for Entrepreneurial Studies' is responsible for educating students on entrepreneurship and new venture creation. These policies is a type of tertiary facilitation that allows students to tailor their learning to their preferences. Universities, through this policy, provide opportunities for students to broaden their insights and competencies in the real world (Peraturan Menteri Pendidikan dan Kebudayaan, 2020). 
The learning process can take place in a variety of situations and settings, not just in the classroom, laboratory, or library. The learning process can take place in the workplace, the community, the village, community social development centers, research centers, and other places and situations. It is hoped that by exposing students to the real world, they will improve their skills, social sensitivity, entrepreneurial spirit, and overall awareness of the reality outside of campus. According to the concept of independent learning policy, there are certain competencies that all students must possess, such as entrepreneurship (Sousa, 2018). Entrepreneurial competence is closely related to students' ability in their environment (Rudmann, 2006). Students must be able to create and grow businesses that are both profitable and have a positive impact on the environment. Entrepreneurship is growing in importance around the world due to its positive effects on employment, productivity, innovation, and economic growth (Sousa, 2018).

The purpose of this study was to determine the impact of project-based learning (PjBL) strategies on the development of entrepreneurial skills of students in both Indonesia and Nigeria. There are numerous studies that show that project-based learning can improve student achievement, one of which is (Almulla, 2020). According to Almullah (2020) PjBL techniques can increase student engagement by facilitating knowledge and information sharing and discussion. As a result, the PjBL approach is highly recommended for students to use and should be encouraged by universities. Then (Gai Mali, 2016) discovered that using PjBL can increase student participation in learning as well as teacher innovation in teaching. The use of $\mathrm{PjBL}$ appears to assist students in practicing real-life tasks in accordance with the demands of the IQF and independent learning that they may be required to do after graduation. Furthermore, (Ismuwardani et al., 2018) discovered that PjBL can boost students' creativity and independence. Because PjBL is centered on student activities during the learning process and will produce products at the end of learning, it is an appropriate learning model that can be applied in the learning process. However, (Kizkapan \& Bektas, 2017) mentions that students who are accustomed to traditional learning may struggle to adapt to PjBL. Students who are used to teacher-centered instruction may struggle with PjBL. Nigeria and Indonesia were different in developing entrepeneurial skill. In Negeria, they have Chike Okoli Centre for Entrepreneurial Studies (COCES) that engaging Unizik Undergraduates and COCES external students in quality entrepreneurial studies, it will set in them the right mindset that will transform them from 'take-a-job mentality' into 'make-a-job mentality'. It also provide market linkages, collaboration and partnership with institutions and funding agencies and also provide trainings through conferences, seminars, workshops etc, in the area of entrepreneurship and career awareness. The urgention of PjBL for entrepreneurial skill to ensure that students acquire utility skills in the preparation of business plans and project execution.

The importance of entrepreneurial skills for students and the impact of PjBL strategies, this research seeks to delve deeper into the role of $\mathrm{PjBL}$ in improving entrepreneurial skills. This research was conducted in two countries, Indonesia and Nigeria, it is novel and has never been done before. This study encourages all educators to use $\mathrm{PjBL}$ so that students can produce products from each lecture process. Entrepreneurial skills are a way of describing entrepreneurial competence. Competence in entrepreneurial skills is essential for successfully starting a business and maintaining long-term profitability (Astuti et al., 2019). This paper's research question was how the project-based learning process was carried out in order to improve entrepreneurial skills. What products have resulted from the project-based learning process at the end of the course? This research will provide information about how the PjBL process works, and the findings can be used to gain insight and as a reference for implementing $\mathrm{PjBL}$ in lectures. This study is expected to provide an alternative option for developing entrepreneurial skills through project-based learning in both Indonesia and Nigeria, particularly at Universitas Bengkulu, Nnamdi Azikiwe University, and other institutions.

Before starting a business in any field, anyone who wants to be an entrepreneur must have an entrepreneurial spirit. Without a strong entrepreneurial spirit, the business may come to a halt or even go bankrupt due to insignificant causes (Saragih, 2017). Being entrepreneur they should understand how to organize, manage, and takes risks in order to create new businesses and business opportunities (Ananda \& Rafida, 2016) (Alfianto, 2012). Entrepreneurial characteristics can help people who are starting their own businesses (Ananda \& Rafida, 2016). Entrepreneurship teaches creative, innovative, and positive ways of thinking, and moves the conscience to be more proactive, change, encourage curiosity, be tenacious, persistent, and dare to take risks to do things that have never been done before but will bring added value and greater profits (Ananda \& Rafida, 2016). Entrepreneurial behavior demonstrates a person's ability to plan ahead, think logically, and seek options from a variety of alternative problems and solutions (Sukirman, 2017).

Project-based learning encourages students to conduct research, solve problems, be student-centered, and create tangible products (Ismuwardani et al., 2018) (Gai Mali, 2016). A significant feature of PjBL is the active involvement of students in the learning process. PjBL teaches students not just content, but also important skills in ways students have to be able to function like adults in our society. These skills include 
communication and presentation skills, organization and time management skills, research and inquiry skills, self-assessment and reflection skills, group participation and leadership skills, and critical thinking (J. Stivers \& Brandon, 2010). PjBL is useful for teaching Linguistic Research and Education, as well as providing students with hands-on experience in writing research proposals (Wahyuni, 2014). The PjBL had a significant effect on students' speaking ability (Rohmahwati, 2016). The teaching of biology with PjBL resulted in both increased motivation among students and more positive attitudes towards biology (Kortam et al., 2018), and (Isa et al., 2020) PjBL was effective tool for engaging students in activities that develop their level of creativity, communication skills, and critical thinking. Then (Wulandari et al., 2021) utilized quasi experimental techiques to investigate the impact of $\mathrm{PjBL}$ on students' creative thinking skill related to playing musical instruments. The average score for creativity was higher for students who were engaged with PjBL and lower for those who were not. This is an indication that $\mathrm{PjBL}$ brings out the best in students.

\section{Method}

This qualitative study looks at how project-based learning is implemented and how it can help people develop entrepreneurial skills in both Indonesia and Nigeria. This research is carried out directly by us and involves students as research objects who will create projects and be evaluated at the end of the lecture (Somantri, 2005) (Tobing et al., 2016). This study takes place at Universitas Bengkulu and Nnamdi Azikiwe University in Awka, Nigeria. Participants were 20 students from Nnamdi Azikiwe University, Awka, Nigeria and 40 students from Universitas Bengkulu. The participants were enrolled in entrepreneurial courses in the university. This courses were centered and taught through PjBL approach. The aim of this qualitative analysis was to access the participants' entrepreneurial skill development, and creative thinking ability attached to problem solving. After exposing the students to the entrepreneurial courses, the participants were evaluated and their qualitative responses were used for the interpretation of results. This study's informants were students enrolled in Entrepreneurship Courses in Universitas Bengkulu and Nnamdi Azikiwe University in Awka, Nigeria. An observation sheets for looking at the project and students' project documents were used as data collection techniques. The data analysis technique used the Miles and Huberman analysis technique, which was carried out by us to obtain research results that included data reduction activities, data display and conclusions, or data verification. Then, examine the student projects.

\section{Results and Discussions}

PjBL's stages in this study were 1) Project Determination; 2) Project Step Planning; 3) Schedule Preparation; 4) Monitoring; 5) Report Preparation and Presentation; and 6) Project Evaluation (Ismuwardani et al., 2018) (Gai Mali, 2016). All the stages were done by the students. The steps of PjBL for entrepreneurial skill development was written in the Lesson Plan. The project reports of students in Universitas Bengkulu are available in https://osf.io/au87c/quickfiles.

This study also discovered what (KeyValuePair, 2019) found in his research: Nigeria's unemployment rate has been increasing at an alarming rate over the years. The Federal Ministry of Education revealed a concerning trend: more than sixty percent of graduates are either unemployed or underemployed, necessitating entrepreneurial training for millions of unemployed youths.

The study discovered a link between entrepreneurial education and entrepreneurial intentions. The magnitude of the relationship between entrepreneurial education and entrepreneurial intention was deemed modest. The finding is critical in the sense that entrepreneurship needs to be given the attention it deserves in the university curriculum in order to help solve the country's problems of unemployment, poverty, and underdevelopment. It recommends that entrepreneurship education be taught at the primary, secondary, and tertiary levels of education in order to instill an entrepreneurial spirit in Nigerian citizens from childhood. Entrepreneurship education curricula should be practical, appealing, and functional in order to create the necessary jobs, rather than simply teaching/learning principles and theories. Universities and other tertiary institutions should offer scholarships to lecturers interested in pursuing a career in entrepreneurship.

Entrepreneurship development in Nigeria based on our observastion is not a new phenomenon; it has existed since the beginning of time. It all started when man set out on his quest to create and amass wealth. It also emphasizes the fact that in order for man to be happy, he needed to spread wealth. This was regarded as the beginning of early entrepreneurship in Nigeria.

While we were doing observation, learners in Nigeria can develop key entrepreneurial skills such as creativity, critical thinking, problem solving, communication, reasonable risk-taking, self-motivation, financial responsibility, and teamwork. It teaches students to think outside the box and become job creators rather than 
job seekers, which helps to lower the unemployment rate. Furthermore, by allowing them to start enterprises based on their hobbies, abilities, or careers, the unemployment rate is reduced as these businesses expand and create new job opportunities. This education also teaches youths to be self-sufficient and confident in their talents, allowing them to take calculated chances in order to succeed and become self-sufficient once they do.

According to The Nigerian Voice, Nnamdi Azikiwe University opened its doors on March 19, 2018 to expose its students to three major areas of agro-preneurship, entrepreneurship, and trans-preneurship. The vice chancellor stated that the university had begun producing quality bread and other confectionaries through its women cooperative society. These deliberate attempts, he claims, were made to further position the college as an entrepreneurial university. "The time has come to show our abilities and skills in assisting students in embracing 21st-century research that will prepare them for life beyond graduation."

The results of the observation sheet in Nnamdi Azikiwe University indicated that PjBL approach increases students' entrepreneurship skill development, creative thinking, and problem solving. These are very important for future entrepreneurial endeavours. Hence, $\mathrm{PjBL}$ is an effective method that can be used to enhance the entrepreneurial skill of students compared to the traditional class structure where the teacher or lecturer do more of the teaching with less students' involvement. The results of the study was in congruence with the extant literature.

In Bengkulu, Indonesia, based on students' project documents were many innovations and creativities of students when they study entrepreneurship through project based learning. There some students made nugget and it is sold out in Bengkulu area.
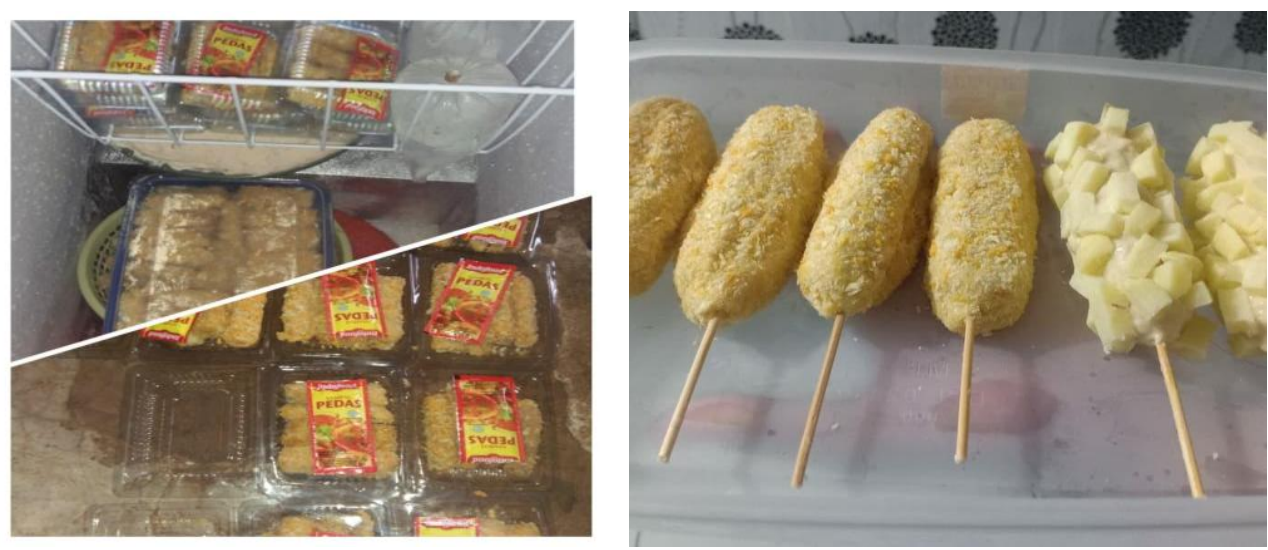

Figure 1. Nugget was made by Aufatallah Dzaki Aldero, Desta Fitriani and Aida Fareza

Some students also made "Mardaebak Mini" and it sells online by using WhatsApp, Instagram and Tiktok.
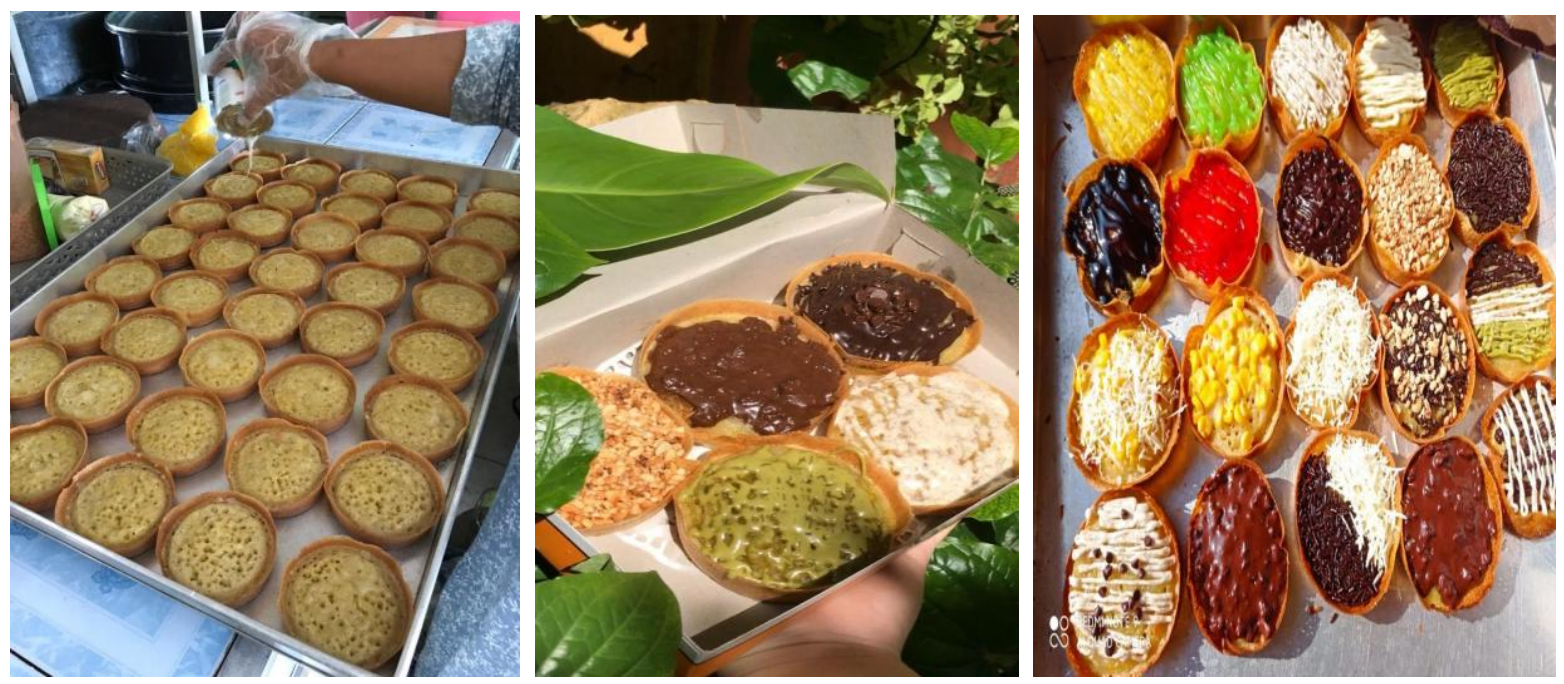

Figure 2. "Mardaebak Mini" was made by Muhammad Satya Adipura, Diah Indah Relinsa, and Aulianisa Briliani 
There is also a student-created cafe that serves coffee specialties in Rejang Lebong, Indonesia, and he donated a film that is shown on a projector. Customers are eager to come in, drink a cup of coffee, and watch a movie. The student was creative; he created the brand Ngofi (Ngota Film), which means "film watching." The cafeteria's name was also intriguing: "Korelasi" Kopi Rejang Lebong Asli is abbreviated as Korelasi.

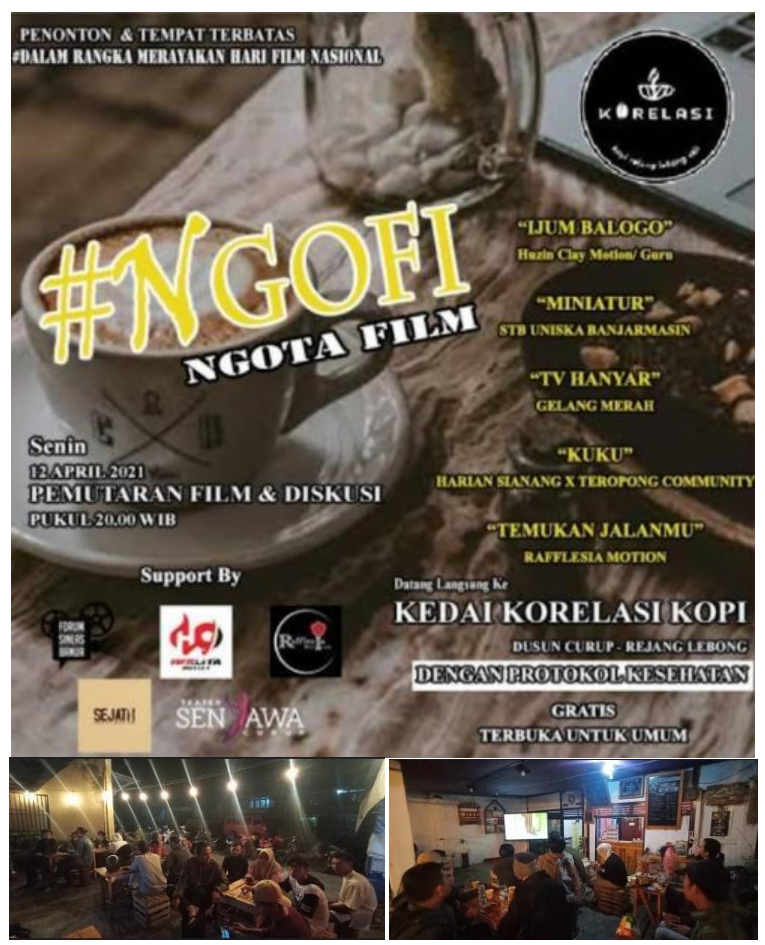

Figure 3. "Korelasi" was made by Daniel Dwi Putramanik

Other student made "Keripik Bayam" spinach chips and "Kripik Pare" bitter melon chips. With an initial capital of Rp. 65,000, she produces 21 packs of chips in one production. She sells Rp. 5,000 per pack, so her profit in one production is Rp. 40,000 .
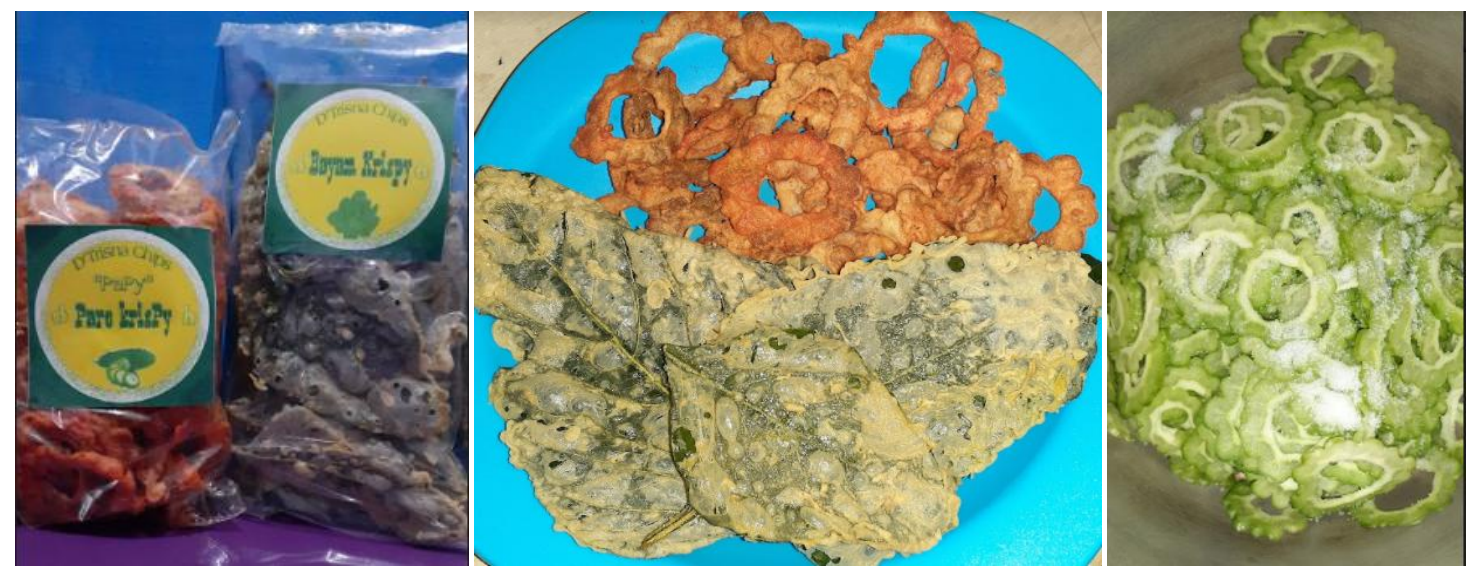

Figure 4. "Keripik Bayam" and "Kripik Pare" was made by Dian Eka Trisnawati

Dido Ronel makes mussel crackers. The cracker is from the Indonesian town of Rejang Lebong. Many visitors buy crackers, including the mayor of Rejang Lebong, who visits and purchases them. Dido Ronel has a quote "enjoy the charm of Lebong Regency and bring the kijing crackers". 


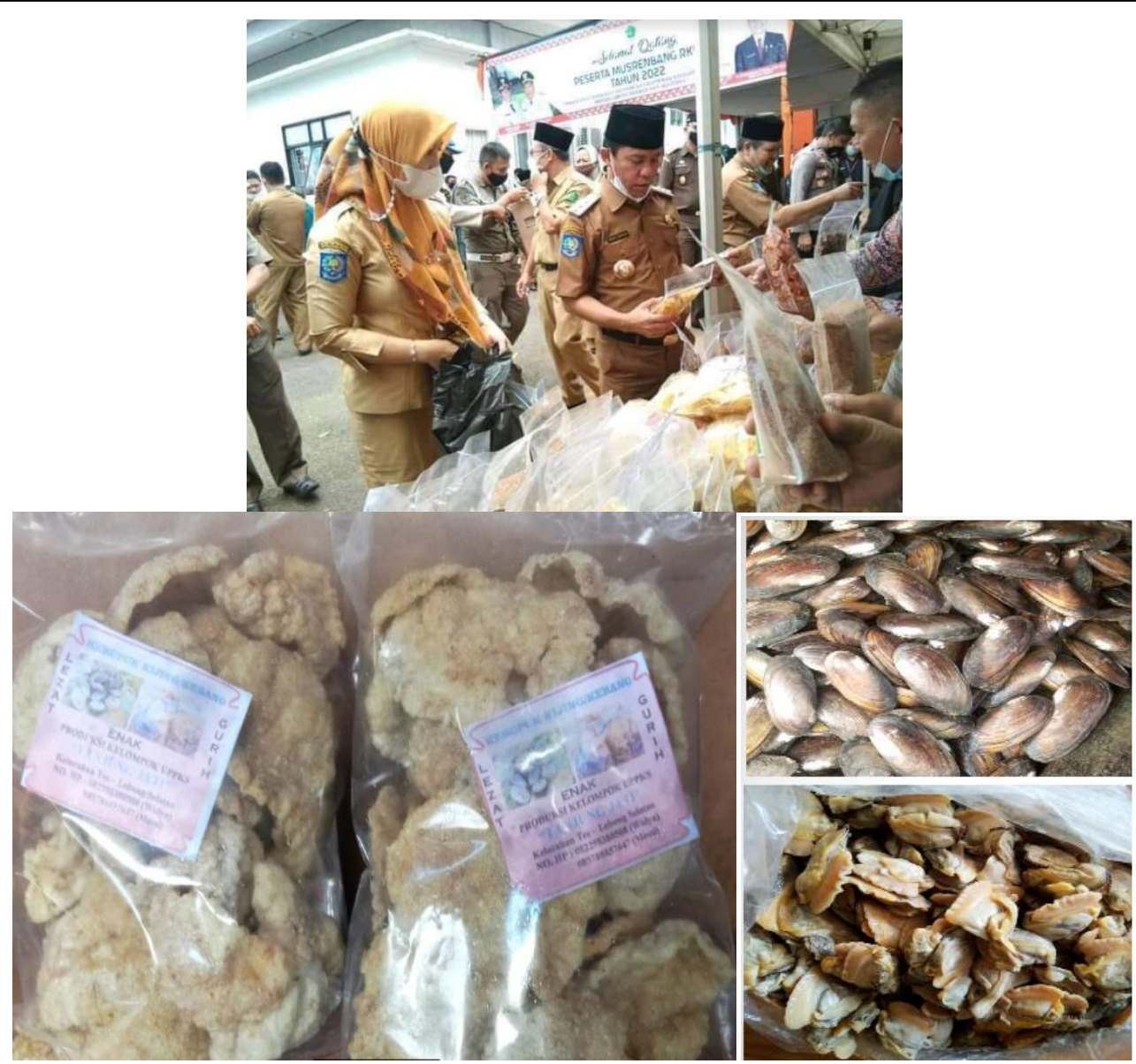

Figure 5. Kijing Crackers made by Dido Ronel and Mayor of Rejang Lebong Purchases Them

Putri Andhini, the creator of Dr. Koffee, also sells various types of coffee and methods of making coffee that local coffee enthusiasts are interested in, as well as some snacks. The coffee shop business has boomed in recent years, owing to the large number of young people who are interested in coffee and places to hang out with a cozy cafe feel to simply have a warm conversation with their closest friends.
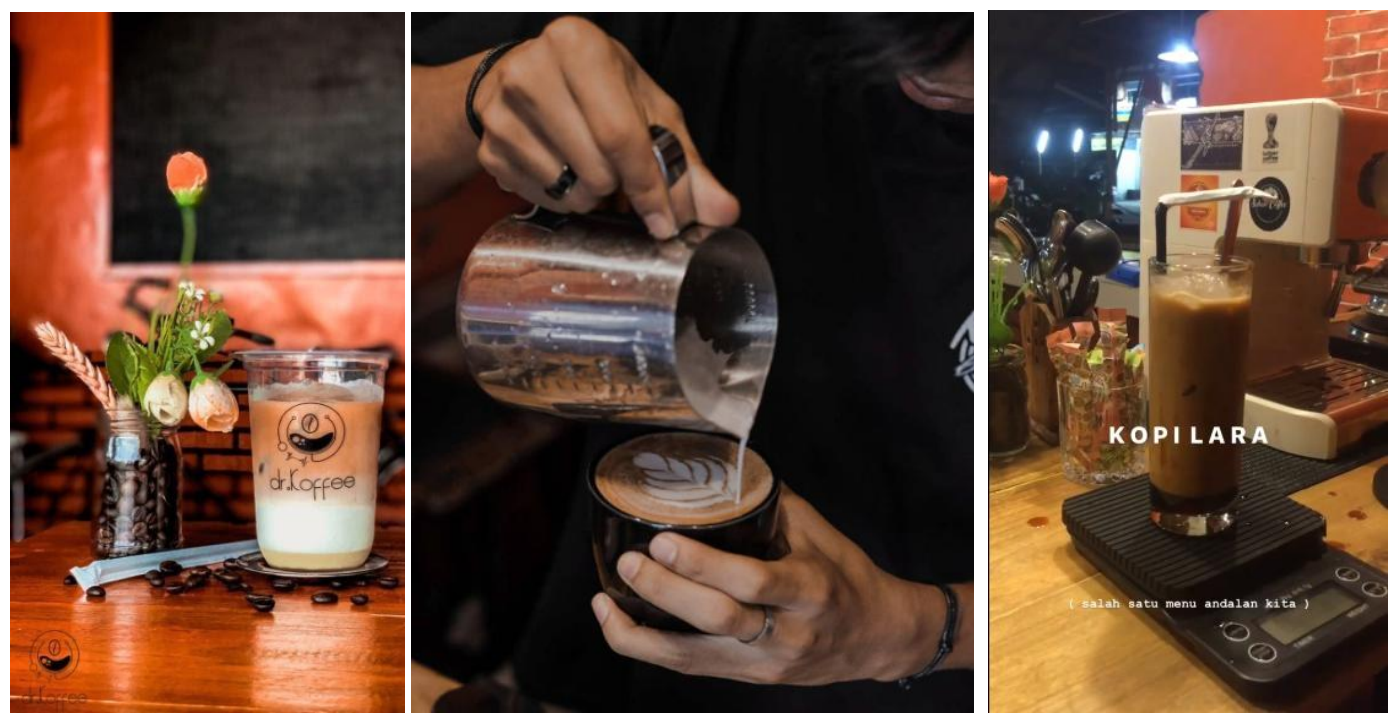

Figure 6. Putri Andhini, the creator of Dr. Koffee

Entrepreneurial skill of students both in Indonesia and Nigeria could be developed by using PjBL. This study was supported by (Olukundun, 2017) found that entrepreneurship education affects students' learning 
orientation and expression of entrepreneurial implementation intentions in Nigerian universities. These Universities are Federal University of Technology Akure, Ondo state, Federal University of Agriculture Abeokuta, Ogun state, Joseph Ayo Babalola University Ikeji Arakeji, Osun state and Lead City University Ibadan, Oyo state. Implementing project-based learning in entrepreneurship learning was able to improve students' entrepreneurial intention as well as their entrepreneurship learning outcome (Darmawan \& Soetjipto, 2016), and there is a significant difference in students' understanding of the concept of entrepreneurship and the formation of an entrepreneurial mindset when they participate in project-based learning (Sukerti et al., 2019). According to (Torrance et al., 2013), universities play a critical role in creating an environment that encourages students to engage in entrepreneurial behavior by connecting their research and students' education to emerging industry interests.

The result of this study states PjBL is effective for student's skill of entrepreneurship, students can use core academic and creative skills to solve salient problems in real-world business situations when using the project method of teaching (Birney et al., 2017). Students should also be given the chance to choose entrepreneurship topics of interest within the specified content framework, and they should be responsible for developing project plans (Olukundun, 2017). Entrepreneurship courses must adopt more practical pedagogical approaches to assist students in interpreting information and effectively identifying new business opportunities. This paper used PjBL and (Rokhmaniyah et al., 2020) used Elementary school students' entrepreneurial spirit can be cultivated through STEAMS-based entrepreneurship learning. It advises practitioners, researchers, and stakeholders to use STEAMS to empower entrepreneurship in elementary school. Entrepreneurship education is a type of learning that includes elements of activities in a production-based learning approach and can help to develop entrepreneurial characteristics such as communication skills and teamwork (Yuliana \& Hidayat, 2019). According to (Piperopoulos \& Dimov, 2015) there is relationship between students' self-efficacy beliefs and entrepreneurial intentions in the entrepreneurship course's pedagogy. In reality, entrepreneurship education is hostile to the development of entrepreneurial capabilities and skills among university students. If the contents of an entrepreneurship curriculum encourage critical thinking, there is a greater likelihood of generating viable business ideas.

\section{Conclusions}

PjBL approach can help students at Nnamdi Azikiwe University and Bengkulu University improve their entrepreneurial skills, creative thinking, and problem solving. PjBL is an effective method for developing students' entrepreneurial skills.

\section{Acknowledgments}

We would like to express our special thanks and gratitude to Rector Universitas Bengkulu, Vice Chancellor, Nnamdi Azikiwe University, Awka, Nigeria, and Dean of Faculty Education Universitas Bengkulu who gave us the golden opportunity to do this wonderful project. Secondly, we would also like to thank our friends in Universitas Bengkulu and Nnamdi Azikiwe University who helped us a lot in finalizing this project within the limited time frame.

\section{References}

Alfianto, E. A. (2012). Kewirausahaan : Sebuah Kajian Pengabdian kepada Masyarakat. Heritage, 1(2), 33-42.

Almulla, M. A. (2020). The Effectiveness of the Project-Based Learning (PBL) Approach as a Way to Engage Students in Learning. SAGE Open, 10(3). https://doi.org/10.1177/2158244020938702

Ananda, R., \& Rafida, T. (2016). Pengantar Kewirausahaan Rekayasa Akademik Melahirkan Enterpreneurship. In Perdana Publishing (Issue Rekayasa Akademik Melahirkan Enterpreneurship).

Astuti, W., Supanto, F., \& Supriadi, B. (2019). Entrepreneurial Skills and SME's Business Performance: Empirical Study Culinary Business. Journal of Economics and Sustainable Development, 10(22), 160-166. https://doi.org/10.7176/jesd/10-22-17

Birney, L. B., Watson-Currie, E., \& Jha, K. (2017). Curriculum and Community Enterprise for New York Harbor Restoration in New York City Public Schools. Radical Pedagogy, 14(1), 114-127.

Darmawan, I., \& Soetjipto, B. E. (2016). The implementation of project-based learning to improve entrepreneurial intention and entrepreneurship learning outcome of economics education students. Journal of Business and Management, 18(10), 98-102. https://doi.org/10.9790/487X-18100798102

Gai Mali, Y. C. (2016). Project-Based Learning in Indonesian EFL Classrooms: from Theory to Practice. IJEE (Indonesian Journal of English Education), 3(1), 89-105. https://doi.org/10.15408/ijee.v3i1.2651 
Isa, M. U., Kamin, Y. Bin, Salihu, Y. I., Shuaibu, H., \& Cledumas, A. M. (2020). Enhancing employability skills of woodwork technology education students through project based learning at colleges of education (technical) in Nigeria. Universal Journal of Educational Research, 8(9A), 31-40. https://doi.org/10.13189/ujer.2020.082005

Ismuwardani, Z., Nuryatin, A., \& Doyin, M. (2018). Implementation of Project Based Learning Model to Increased Creativity and Self-Reliance of Students on Poetry Writing Skills. Journal of Primary Education, 8(1), 51-58. https://doi.org/10.15294/jpe.v8i1.25229

J. Stivers, \& Brandon, G. (2010). Project-Based Learning Why Use It? Educational Psychology, ESPY 505, 1-8.

KeyValuePair, A. (2019). Students' Entrepreneurial Intentions and Formal Education a Study of Selected Universities in South-Southm Nigeria. NG-Journal of Social Development, August. https://platform.almanhal.com/GoogleScholar/Details/?ID=2-139715

Kizkapan, O., \& Bektas, O. (2017). The effect of project based learning on seventh grade students' academic achievement. International Journal of Instruction, 10(1), 37-54. https://doi.org/10.12973/iji.2017.1013a

Kortam, N., Basheer, A., Hofstein, A., \& Hugerat, M. (2018). How Project-Based Learning promotes 7 th grade students ' motivation and attitudes towards studying biology. Action Research and Innovation in Science Education, 1(2)(August), 9-17.

Nnamdi Azikiwe University. (2011). Chike Okoli Centre for Entrepreneurial Studies (COCES). https://coces.unizik.edu.ng/about-us/

Olukundun, M. A. (2017). Pecerptions of students on entrepreneurship education and entrepreneurial intentions in selected Nigerian universities. 25-236. http:// eprints.covenantuniversity.edu.ng/9506/1/Ayodele.pdf

Peraturan Menteri Pendidikan dan Kebudayaan. (2020). Peraturan Menteri Pendidikan Dan Kebudayaan Nomor 03 Tahun 2020 Tentang Standar Nasional Perguruan Tinggi.

Piperopoulos, P., \& Dimov, D. (2015). Burst Bubbles or Build Steam? Entrepreneurship Education, Entrepreneurial Self-Efficacy, and Entrepreneurial Intentions. Journal of Small Business Management, 53(4), 970-985. https://doi.org/10.1111/jsbm.12116

Rohmahwati, P. (2016). Project-Based Learning To Raise Students' Speaking Ability: Its' Effect and Implementation (a Mix Method Research in Speaking Ii Subject At Stain Ponorogo). Kodifikasia, 9(1), 199. https://doi.org/10.21154/kodifikasia.v9i1.466

Rokhmaniyah, R., Suryandari, K. C. (2020). Steams-Based Entrepreneur Curriculum Development by Empowering Local Potential for Elementary Students. International Journal, $X(\mathrm{X}), 66-77$. https://doi.org/10.20961/ijsascs.v4i1.49459

Rudmann, C. (2006). Entrepreneurial Skills and their Role in Enhancing the Relative Independence of Farmers. In FiBL. http://orgprints.org/18064/1/rudmann-etal-2008-esof.pdf

Saragih, R. (2017). Membangun USAha Kreatif, Inovatif dan Bermanfaat melalui Penerapan Kewirausahaan Sosial. Jurnal Kewirausahaan, 3(2), 26-34.

Somantri, G. R. (2005). Gumilar Rusliwa Somantri. Makara, Sosial Humaniora, 9(2), 57-65. https://media.neliti.com/media/publications/4388-ID-memahami-metode-kualitatif.pdf

Sousa, M. (2018). Entrepreneurship Skills Development in Higher Education Courses for Teams Leaders. Administrative Sciences, 8(2), 18. https://doi.org/10.3390/admsci8020018

Sukerti, N. W., Mukhadis, A., Kiranawati, T. M., Suswanto, H., \& Nurhadi, D. (2019). The Effect of projectbased learning which integrates Tri Kaya Parisudha concept and emulation ability on students' comprehension and formation of an entrepreneurial mindset. International Journal of Innovation, Creativity and Change, 8(1), 324-343.

Sukirman, S. (2017). Jiwa Kewirausahaan dan Nilai Kewirausahaan Meningkatkan Kemandirian Usaha melalui Perilaku Kewirausahaan. Jurnal Ekonomi Dan Bisnis, 20(1), 117. https://doi.org/10.24914/jeb.v20i1.318

Tobing, D. hizki, Herdiyanto, Y. K., \& Astiti, D. P. (2016). Bahan Ajar Metode Penelitian Kualitatif. Program Studi Psikologi Fakultas Kedokteran Universitas 42. https://simdos.unud.ac.id/uploads/file_pendidikan_1_dir/870ba33936829bb37ecd8f62f8514ba7.pdf

Torrance, W. E. F., Rauch, J., Aulet, W., Blum, L., Burke, B., D’Ambrosio, T., de los Santos, K., Eesley, C. E., Green, W. S., Harrington, K. A., Jacquette, J. P., Kingma, B., Magelli, P. J., McConnell, G., Moore, D., Neeley, L., Song, M., Tan, T.-K., Zoller, T., \& Zurbuchen, T. (2013). Entrepreneurship Education Comes of Age on Campus: The Challenges and Rewards of Bringing Entrepreneurship to Higher Education. SSRN Electronic Journal. https://doi.org/10.2139/ssrn.2307987

Wahyuni, S. (2014). the Implementation of Project-Based Learning To Direct Students in Writing a Research Proposal. Language Circle - Journal of Language and Literature, 8(2), 193-205. https://doi.org/10.15294/lc.v8i2.3023

Wulandari, D., Rahayuningtyas, W., \& Widyawati, I. W. (2021). Pengaruh Model Project Base Learning terhadap Kemampuan Berpikir Kreatif pada Materi Bermain Alat Musik Sederhana di SMP Negeri 3 
Singosari. JoLLA: Journal of Language, Literature, and Arts, 1(3), 320-330. https://doi.org/10.17977/um064v1i32021p320-330

Yuliana., \& Hidayat, H. (2019). How Is the Student's Personality in Implementing Science and Technology for Entrepreneurship Learning with a Production-Based Learning Approach in Higher Education? Journal of Engineering and Applied Sciences, 15(1), 213-219. https://doi.org/10.36478/jeasci.2020.213.219 